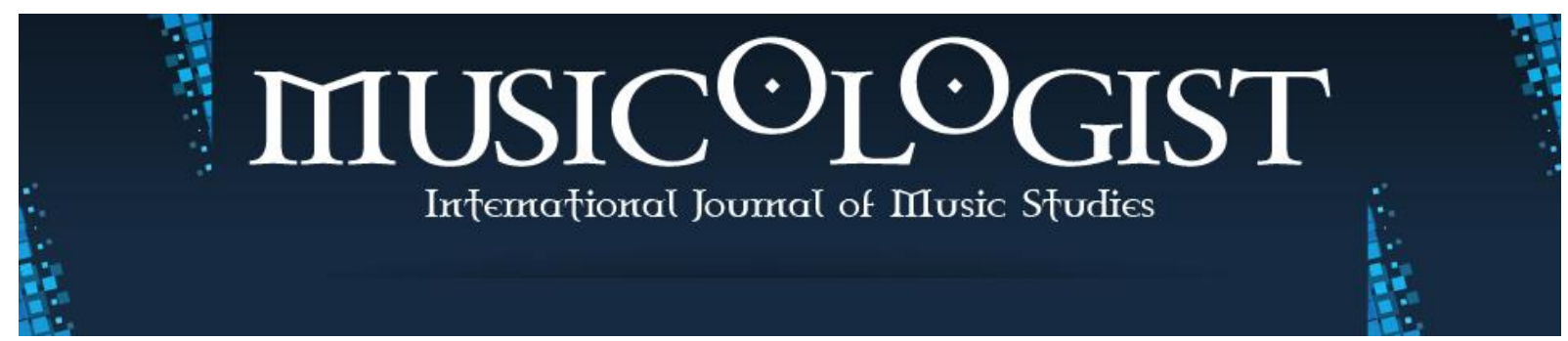

Trabzon University State Conservatory @ 2017-2019

Volume 3 Issue 2 December 2019

Research Article

Musicologist 2019.3 (2): 178-191

DOI: $10.33906 /$ musicologist.660768

\title{
BELMA OĞUL
}

Istanbul Technical University, Turkey

belmak65@gmail.com

orcid.org/0000-0002-5042-6953

\section{Where is the Homeland in My Music?: Interhomelands Migration*}

\begin{abstract}
There are different types of migration, however, new concepts and redefinitions of certain concepts are needed, because of the changing reasons for migration as well as various imaginings of the places and spaces in concrete and virtual terms. This paper coins the phrase 'interhomeland migration' as a type of migration through addressing how the concept of homeland is constructed through affect, and who constitutes this migrant type.

The data, obtained from fieldwork executed with those who identify themselves as Bosniaks (especially in Istanbul and nearby cities) since 2004 and with the Turkish-speaking people living in Bulgaria between 2013 and 201,5 is assessed by the means of analyses of both the discourses and various musical elements. In these examples, the affect of homeland is constituted by religion, flag, blood, land, especially fighting for the sake of this land, vague and non-objective nationalist concepts, shared historical and cultural background, such as musical values in addition to born and grown lands. Interhomelands migrant type experiences the affects containing contrasts all together such as feeling alike, feeling strange, feeling the belonging. These affects cause to uncover the similarities on the one hand and on the contrary to underline the dissimilarities on the other hand.
\end{abstract}

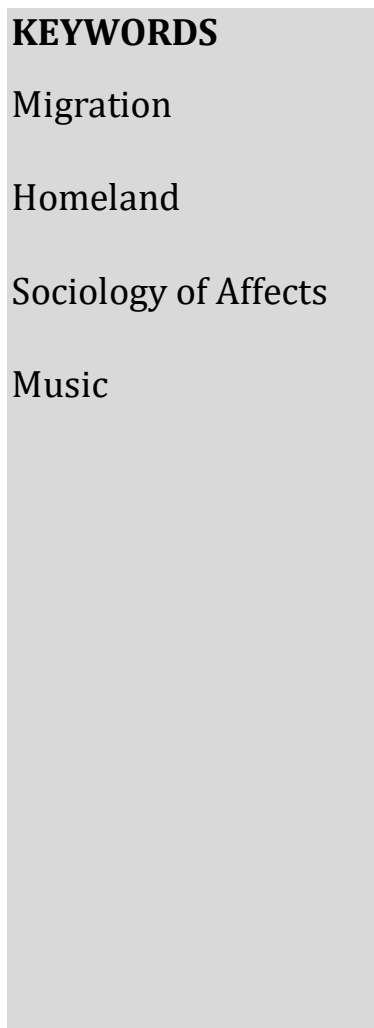

\footnotetext{
* This paper is the extended version of the presentation submitted in the $3^{\text {rd }}$ International Music and Dance Studies Symposium in Trabzon in 17-20.10.2018
}

Received: December 18, 2019; Accepted: December 26, 2019 
There are different types of migration, mostly defined according to borders or to reasons. It seems that we will experience mass movements of populations more frequently in the near future. Therefore, new concepts and redefinitions are needed for these different ways of mobilization, as well as replacements, since the conditions, legislations, and most importantly, the world order are changing.

Based on the studies of the Bosniak people living in Turkey conducted since 2004, and of the Turkish-speaking people living in Bulgaria between 2013-2015, I have realized that their discourses and the lyrics of their music reveal their emotions, which are related to their perception of homeland, while they are mentioning their cultural identity, as well as their migratory identity. The social identity and cultural identity are both composed of some elements in an alternating hierarchy according to various conditions. These elements may be language, religion, education, socio-economic conditions, state of politics, ethnicity, nation, and many others. The social identity is constructed through the relationship with other individuals, other groups of people, other institutions or nations and states, while cultural identity covers many qualifications, such as gender, language(s), religion, daily experiences, and so on. The hierarchically ordered elements of the identity of the Bosniak people living in Turkey and the Turkish-speaking people living in Bulgaria may change according to their homelands and various positive and negative emotions accordingly. Based on the idea that each being is somehow affected by the replacements due to the emergent confronted conditions, the emotions, which may be also politically manipulated, as Han (2019) argues, are very important to understand in which way these emotions are handled to survive.

While trying to understand the relationship between these emotions, migration, and homeland, I have realized that their migration category does not fit any formerly defined ones. Therefore, I have coined the term 'interhomeland' migration, corresponding to this situation. To expand on this interhomeland migration category, I discuss the concepts of migration and homeland, their components and imagination through music and emotion.

\section{Migration and Homeland}

Although migration stands as a conceptualization of macro-political (in which case we can treat politics as the management of emotions), the immigrant's status is micro- 
political; therefore, immigration can be understood through individuals' own affections. Affects and emotions are assumed to vary from person to person within this micropolitic, which is ambiguous, intangible, and can exist at the same time with its contradictions. On the other hand, when the emotions are treated "as a kind of thinking" as Thrift (2004: 60) says, it can be argued that emotions connect the body and things through perception, feeling, expression and intersubjective transmission. Through the social exchanges of communities and individuals, emotions are shared, and convictions arise (see Lawler, 2001 for further discussion). Deleuze (2000: 11) stated that Spinoza thought "the idea comes before emotion", and "to love [we can also call affect in general] it is necessary to have an idea of what is loved, whether it is as much ambiguous or as much confused".

Therefore, an individual has an idea about migration as well as the place, where he or she comes or goes. With this idea, it can be said that positive emotions, such as excitement, pleasure, pride, gratitude, hope in the cases of not entirely forced migrations - depending on where they go - and negative emotions such as sadness, embarrassment, anger, and longing, in the cases of forced migrations are developed. On the other hand, the people who do not migrate, but experience their close friends' and relatives' migration, are affected by this abandonment. However, it is more common to experience both positive and negative emotions at the same time.

As Bayart's (1999) term "illusion of identity" emerges with convictions and emotions, so do the categories of migration. Ulus Baker (2012) mentions that the word conviction is synonymous with 'imagination' but not with 'doxa', and that Spinoza considers convictions as 'obligatory illusions' in Etika (2011). Regardless of the reasons and consequences, this categorization relates to place, which is established in the imagination and, by the obligatory illusions, is not a fixed and unchanging concept other than political reasons, but makes the homeland special, which is constructed and imagined by emotions. We can say that migration between the homelands or multihomelands (Kaiser, 1994: 23) built in connection with these social and political convictions can be addressed through emotions in this context.

Both Bosnian people living in Turkey, and Turkish-speaking Muslim people living in Bulgaria, first immigrated to the Balkan region via Anatolia and the Northern Black Sea 
region during different time periods, and then some of them, with various motives, started to migrate within the borders of today's Turkey starting in the 19th century onwards. The last wave of migration from the Balkans to today's borders was actualized by the Turkish-speaking people in 1989, and by the Bosniaks in early 1990's. Although their motives and the conditions of their migrations vary, both communities have common emotions constituted by their earlier social and political connections with the Ottoman State (Bosna and Herzegovina 1463-1878 and Bulgaria 1371-1878), later dispersed family members living both in Turkey and Bulgaria or Bosnia, Montenegro, Serbia. In other words, they consider themselves as sharing the same ancestry.

The fact that Islam and Turkishness are considered as equivalent in the Balkans gives the feeling of a common consanguinity, per se. The interchangeability of religion and ancestry is often encountered in everyday language, as well as in academic language ${ }^{1}$. Ancestry and consanguinity establish a relationship with the people who make up the imagined homeland. Although it is the subject of controversy that Bosnians are Slavic or Pechenegs from the Northern Black Sea or Turkish principalities from Anatolia, it is an emotional ancestry, not an ethnicity related to blood or language.

Being a cognate includes a broad meaning, extending from today's 'ruled by the same powers once upon a time', to those who have 'common values' of uncertain scope. Both the Bosniaks living in Bosnia and Herzegovina, Montenegro, and Serbia, and the Bosniaks who have migrated to Turkey's borders, bear emotions evoking homeland for all these countries and they mention them with a sense of longing and nostalgia. The same is true in the Bulgarian case. The dispersed family members also keep these emotions alive, both through individual relationships and the exchange of goods, for example the local food, or means of music recordings. Furthermore, these emotions are propagated through some symbols such as the flag, the blood, the earth, the land that has been fought for in music to achieve the imagination of the homeland and common positive and negative emotions.

Bosniaks, for example, had mixed feelings while they were migrating to their new homeland of Turkey, and they started longing for their former homeland after the settlement. They emerge in the discourses about migration constructed by the individual

\footnotetext{
1 The book titled Imagining the "Turc" (Jezernik (ed.) 2012) can be given as an example.
} 
and social emotions and political convictions. In addition to discourse, produced, performed, and consumed music is also a tool that helps identify the emotions about and symbols of the homeland.

\section{Interhomeland}

Homeland has been an ambiguous and non-objective nationalist concept constructed through emotions and symbols that stimulate them - such as the flag, blood, land, and especially the land that was fought for - with the nationalism and the nation-state relations since the middle of the nineteenth century.

Many Muslims in the Balkans, Turkey is being felt as an imaginary homeland, and if not, I am convinced that, at the very least, they sympathize with Turkey. This sympathy sometimes includes complaints such as "you left us here", referring to the period of the Ottoman state and admitting that Republic of Turkey is the continuation of the Ottoman state. In addition to the economic, political, and everyday relations, historically speaking in the words of sevdalinka, we can now see a visible proof that Turkey-produced television series are in great demand from the Balkan countries. From this, we can observe that the Muslims who migrated from the Balkans embrace Turkey, as well as their countries of origin, as homeland as seen in their musical practices.

In order to make sense of migration through emotions, immigrants can be considered as a social type. Baker (2012), who construct their social and cultural identity via many factors, one of which is the migratory factor, shared their discourses and musical practices with us during field research, which allows us to conceptualize interhomeland migration.

It can be said that migration is a set of affects based on belonging, alienation, and similarity. From this point of view, in order to become an immigrant, it may not be necessary to experience "its permanent movement from one place beyond symbolic or political boundaries to new settlements and societies" (Marshall, 1999: 685). Religion, land and place, blood, and other symbols are all factors found in the discourse, attached to interhomeland migration. Moreover, dedicated symbolic meanings of musical instruments can also be clues as to the type of migration. 
When we look at the religious factor, Muslims in the Balkans, and migrants, what causes them to feel Turkey as a homeland, is the holiness referring to the religious feelings found within the meaning of the concept. One of the main reasons stated by the immigrants after 1945 was their inability to live their religion freely in their homeland, which was ruled by the socialist party thereafter. A person who came to Turkey in 1966 said "we would have been gavur (non-Muslim), therefore they do not send us to school. There were teachers, teaching us religion". So, he points out a threat posed by religious education at that time, while by saying that "At present, modern Islam is born in Bosnia. Religious education is given from the first grade". He argues that the conditions of the old homeland are improving (male participant, personal communication, 5 July 2006). ${ }^{2}$ The higher visibility of religion was found not only in the field of education, but revealed by the increasing number of various Bosnian hymn groups performing in traditional manner, or in a symphonically arranged manner, which have triggered religious and 'patriotic' feelings. Since the 1980s, and more frequently after 1990s, ethnic and religious music production has grown and the $\mathrm{NKNM}^{3}$, which initially emerged in the 1960s, began to include hymns and heroic songs. Other examples would be that the inclusion of these hymns into the repertoire of the 'Turbo-folk' artist Halid Beslic (for example, the $0 j$ Zefire Hymn). In the video clips from the countries of former Yugoslavia, weapons were used as decor for each country's own heroism during the 1992-1995 Bosnian war. The most visible reason of 1989 mass migration from Bulgaria to Turkey was also the pressure to convert the Muslim names and surnames into non-Muslim names.

On the other hand, being Muslims did not provide a direct acceptance by the inhabitants under the influence of the 1950's motto of 'One nation, one state, one language, one flag' and it took a long time to convince them that they are Muslims themselves due to a

\footnotetext{
${ }^{2}$ However, after the collapse of Yugoslavia, the Islamic Manifesto, which was written by the first President of Bosnia and Herzegovina, Alija Izzetbegovic in the early 1970s and only published in 1983, led to the revival of Islam in Bosnia. A different danger for the future years is ignored among the citizens of BosniaSancak who receive different educations according to their identities such as Islam, Orthodox and Catholicism.

3 Novo Komponovana Narodna Muzika (newly composed folk music) contains many different genres. Between 1960 and 1980, folk music pieces re-arranged through orchestration in pop and rock genres are called as 'neo-folk' and/or 'turbo-folk'. After 1990, the newly composed folk music is a combined form of folk music organized within the framework of commercial forms, values and techniques, similar to Western commercial dance music and MTV style performances. Prevailing styles in the world music market at that moment, such as Latin music or Indian music, influence turbo-folk as well as pop and arabesque music seen in Turkey. Especially for those who migrated to Turkey in the 1960s NKNM is considered as 'authentic'.
} 
different language conversations. "We said let's go to Turkey, since it is a Muslim country. In Sancak, during Ramadan, everyone fasts, Muslim preachers visit the community. But we came here during Ramadan, everyone eats and drinks in the coffee shops. We were surprised whether we have come to Greece. They still called us gavur because we couldn't speak Turkish." (Hamit Albayrak, personel communication, 12 March 2006). Conversely, the language of the migrants from Bulgaria was Turkish; therefore, they were directly considered Muslim. On the other hand, Islam was not a criterion alone, but the common values imagined had to accompany religion. Thus, they did not prefer to migrate to other Muslim countries.

When we consider the land and place for the interhomeland migration, it is also an important factor for emphasizing the cultural identity. When Bosniaks emigrated to the Turkish border, they were placed in certain cities, and in new neighbourhoods in these cities, especially during the intense waves of immigration, in order to eliminate the domestic public's discomfort. The following migrants opted to settle in the same neighbourhoods. One of the cities with largest Balkan immigrant population is Istanbul, followed by Bursa, and as a region - Thrace.

Istanbul ${ }^{4}$ was the capital city of the Ottoman Empire, even after the dissolution of the Ottoman state, and since it was seen as equivalent to the homeland, it is considered as the first place to settle down by the interhomeland migrants. In terms of the states established in this region, Istanbul has a different importance in almost all the centuries. With the passing of the Ottoman Empire, Istanbul became a different place for the people living in the region compared to the previous periods. Among Bosnians, the saying 'If Istanbul is destroyed one day, the Turks should not be upset; There is Sarajevo.' is very well known. However, at the same time, for Bosniaks, at the same time "Istanbul means immigration and separation" (Bayram, 2011: 55). In addition to the characteristics of Istanbul, the longing for Istanbul, the current political and social structure of the period are also included in sevdalinka-s. The most well-known of these are U Stambolu Na Bosforu. "The poet addresses the Ottoman sultan with the word pasha in this sevdalinka. He describes the death of the Ottoman sultan. It has been said for

\footnotetext{
4 “The word Tsarigrad was used for Istanbul. In the Balkans, it meant 'the city of Caesar' originally, but later the tsar began to be used for the Ottoman sultans. Thus, Istanbul has always been the city of Sultans for Bosnians." (Bayram, 2011: 58)
} 
Sultan Abdulmecid I. He is very sick and dying. He says that the servants remained faithful to him and that the sultan was very sad." (Bayram, 2011: 62)

Lyrics of $U$ Stambolu Na Bosforu

$\begin{array}{ll}\text { U Stambolu Na Bosforu } & \text { l to the Bosphorus in Istanbul } \\ \text { Bolan Paša Lezi } & \text { Bolan Pasha lies in the tomb } \\ \text { Duša mu je na jeziku, } & \text { His heart in his mouth, } \\ \text { K Crnoj Zemlji Bježi } & \text { He escaped from the black earth } \\ \text { Dvori, ljubo, dvori, sejo! } & \text { Get ready my favourite, get ready Sejo! } \\ \text { Ko Mujezin Sa Minare } & \text { Like muezzin in the minaret } \\ \text { Uč'te Glasom svim } & \text { Read lush } \\ \text { Allah, Illalah, Selam alejkum! } & \text { Allah, Allah, may Allah bless you! } \\ & \\ \text { Dvorite, me službenici } & \text { Servants serve me } \\ \text { Što služiste Harem } & \text { Like the service in the harem } \\ \text { Svaki Od Vas neka Uzme } & \text { Everyone takes it from you } \\ \text { Jednu ženu barem. } & \text { One woman at least } \\ \text { İz Oka mu Suza Kanu } & \text { Tears are pouring from your eyes } \\ \text { i na Minder Mrtav Panu } & \text { Lifeless, fell on the mat } \\ \text { Stari Musliman } & \text { Old Muslim } \\ \text { Allah, Illalah, Selam alejkum! } & \text { Allah, Allah, may Allah bless you! } \\ \text { Kad je čula Pašinica } & \\ \text { Za Tu Tužnu Vijest } & \text { When the lady of Pasha heard } \\ \text { Da se Paša Preselio } & \text { That sad news } \\ \text { Na taj drugi svijet, } & \text { That Pasha was dead. } \\ \text { İz Oka joj Suza Kanu, } & \text { Hereafter } \\ \text { Pa na Minder Mrtva Panu } & \text { Tears flowing from Pasha's lady } \\ \text { Ljubav Pašina } & \text { Lifeless fell on the mat } \\ \text { Allah, Illalah, Selam alejkum! } & \text { Pasha's lady } \\ & \text { Allah, Allah, may Allah bless you! } \\ & \end{array}$

The places and the constructions, which are the tangible heritage of the Ottoman State, are also symbols for the Turkish identity found in the Balkan countries. For example, Yedi Kızlar Camii (Mosque of the Seven Girls) is a well-known and enchanted mosque in Kirkovo-Bulgaria, with the sacred number seven in its name. The distant past - the epitaph of the mosque shows the foundation date as 1428 - legitimizes the rooted existence of the Turkish-speaking people. The tradition, Hıdırellez, is Islamicized, by reciting Kuran and mevlid to celebrate it in the mosque, which allows the mosque to 
become a larger community place and refreshing memories related to the Ottoman period, both in terms of place, religion and land, for which blood is shed.

Yemen Türküsü (2015)

Erkek:

Alıverin püsküllü çantamı

Takayım koluma

Aman aman bedel de tutmuyor

Gideyim yoluma

Aman aman bedel de tutmuyor

Gideyim yoluma

Kız:

Gel gitme gelin, eşim gel gitme

$\mathrm{Bu}$ gece yatalım

Al çeyizimi satalım be babam

Yare bedel tutalım

Al çeyizimi satalım be babam

Yare bedel tutalım

Erkek:

Sesle ey garip anam sesle, Yemen'i sesle

Yemen'den gönderdim kuruca güller kız elle mi besle

Yemen'den yolladım kuruca üzümler kız elle mi besle

Kız:

Şu karşıda görünen meralar otlu yapraklı Benim de yârimi Yemen'e götüren soğuk toprak mı?

Benim de yârimi Yemen'e götüren soğuk toprak mi?
Man:

Take my tassled bag

Let me hang it to my arm

Oh, can't even afford the paid military service

Let me go my way

Oh, can't even afford the paid military service

Let me go my way

Woman:

Don't go my dear spouse, don't go

Let's lay here tonight

Take my dowry and let's sell it father

Let's pay for my lover's military service

Take my dowry and let's sell it father

Let's pay for my lover's military service Man:

Listen my poor mother listen, listen to Yemen

I sent dried roses from Yemen

Does she feed with her hands

I sent raisins from Yemen

Does she feed with her hands

Woman:

Those pastures seen over there are with grassand leaves

Is it the cold soil that takes my lover to

Yemen?

Is it the cold soil that takes my lover to Yemen?

Similar narratives are seen among the Turkish people living in Bulgaria, in other words, dying and shedding blood for the land. Çanakkale türküsü ${ }^{5}$ and Yemen türküsü 6 are in their repertoire and they connate their deep roots to the history of the Ottoman State, as well as Republic of Turkey, since the Çanakkale war is considered as a very early war of

\footnotetext{
5 It is written for the Çanakkale (Dardanelles) war taken place in 1915-1916.

${ }^{6}$ It is written for the Yemen war taken place in 1914-1916.
} 
independence. As a contemporary citizen of Bulgaria, being a part of the Ottoman past promotes the identity of Turkishness, as well Islamism and emotions of belonging with their heroic and brave roles in the wars.

Another reason why the Bosnians considered the Ottoman lands as homeland could be that the political and military importance of Bosnia and Herzegovina, as well as Serbia, was due to the them being border provinces of the Ottoman Empire, and the fact that many Bosniaks played important roles in the Ottoman Empire ${ }^{7}$. So, they served in the army and lost their lives for the state.

Balkan wars (1912-1913), the Çanakkale war (1915), the Cyprus Peace Operation $(1974)^{8}$, the Bosnian War (1992-1995) are found in the narratives and songs while the Balkan immigrants living in Turkey are articulating their bravery and devotion.

The symbols, such as the flag, the crescent moon and the star, and the fez are the other factors producing emotions and affects describing interhomeland migration. The importance of the flag in the creation of this emotion, was mentioned in an interview by one of the interlocutors. "[When we were at Sancak] we would carry both Turkish and Yugoslavian flags at weddings" (Abdi Bay, personel communication, 21 August 2006), which is also true for the Bosniaks living in Turkey, who carry the flags of Turkey and Bosnia and Herzegovina. The marks on the flag, in other words, the crescent moon and the star, are seen on many tombstones of Muslim people in Balkan countries. Another symbol is the fez, which is seen on album covers and on the stage performances of traditional music and Islamic hymns, and also used as a folk costume in the staged folk dances in Bosnia in order to evoke traditionalism and Ottomans.

Musical instruments are also used as musical and visual symbols among the interhomeland migrants. The music and musical instruments of the old homeland where the migrants were born, grew up, or never even been, from but where some of their

\footnotetext{
${ }^{7}$ For example, one of the grand viziers of the Ottoman Empire, Sokullu Mehmed Pasha who was converted to Islam, is likely to come across as carving in the pegbox of the gusla; such as many others, Hersekzade Ahmed Paşa (1497-1516 ), Damad İbrahim Pașa (1596-1601), Lala Mustafa Paşa (1580-1580), Malkoç Ali Paşa (1603-1604), Lala Mehmed Paşa (1604-1606), Derviş Mehmed Paşa (1606-1606), Kara Davud Paşa (1622-1622), Hüsrev Paşa (1628-1631), Topal Recep Pașa (1632-1632), Salih Paşa (1645-1647), Sarı Süleyman Paşa (1685-1687), Damad Melek Mehmed Paşa (1792-1794).

${ }^{8}$ For example; the name of Kamil Balkan from Dacic family, who immigrated to Turkey in 1967 and was killed in Nicosia during his military service in July 22, 1974, was given to a street and an elementary school in Yıldırım neighbourhood in Bayrampaşa district, where most of the population is composed of Bosniaks.
} 
family members came from, "gives confidence to people because they refer to that place and they are happy in the society where music is performed" (Lomax, 1956: 48-50). Even the music, which is sometimes known as belonging to the homeland, but does not meet their taste of music, is perceived as a part of the society, to which they belong, revealing the feelings of nostalgia, and is enough for them to be happy. New arrivals cause to refresh the memories of the previous ones and renew the language they brought from the other homeland with new musical repertoire, along with the musical instruments. On the other hand, they are convinced that their memory misleads them, and that they could learn the 'real' tradition from the newcomers. For example, the accordion replaces the davul-zurna ensemble and the saz (see Talam, 2013), since the migrants of the 1950s brought the accordion and its music repertoire, which was very popular at that time in Yugoslavia. However, the saz is the symbol of Ottoman period for the ex-Yugoslavian people. The gusla is another musical instrument, with its accompaniment to the epica ${ }^{9}$ genre, which express the emotions for the homeland and is typical for the Muslims of Bosnia and Herzegovina and its surroundings, as well as for Serbs and Croats. In the past, the urban Muslim population had a tradition of storytelling with music, but today, it is still preserved in Muslim villages. It is used as an oral history transfer, since it covers events such as epic poems, accompanied by music, heroism, tradition of telling legends, war, earthquake, fire, epidemic, famine, and drought. According to a a gusla maker in Istanbul, the peg box of the gusla is carved to show some symbols such as Fatih Sultan Mehmed, who was the conqueror of Bosnia and Herzegovina in 1463, and Atatürk. Jusuf Mehonjic from Sandzak, like other Muslim heroes, such as Reco, Dizdar Agha, and Musa Kesiç found in the epica, was also conveyed by the immigrants to Turkey, so that they keep the feelings alive against their former homeland. The migrants tell many stories about Jusuf Mehonjic and his heroism, proving that he is still considered a folk hero.

Finally, there are a number of Sevdalinka which express the migration and migration connotations. There are two examples below that are also known very well and performed by the Bosnian people living in Turkey. The first one is Put putuje Latif-aga which expresses the longing of two friends, who have settled in Bursa, for their

\footnotetext{
${ }^{9}$ Heroic songs, in other words junacke pjesme in Serbo-Crotian.
} 
homeland. It is performed by many artists with different words, but the example here is taken from Safet Isovic (Various Artists, 2007).

\section{Lyrics of Put putuje Latif-aga}

Put putuje Latif-aga

sa jaranom Sulejmanom.

"Moj jarane, Sulejmane!

Je l' ti zao Banja Luke?

Banjaluckih teferica

kraj vrbasa, aksamluka

kraj vrbasa, asıkluka
Latif-Agha sets out

With his friend Süleyman.

"My friend, Süleyman!

Do you feel sorry for Banja Luka?

The countryside of Banja Luka

Next to willow tree in the evening meeting

Next to the willow tree, in times of love

The other example is the song called Stari Aga (Old Agha), which mentions longing for the homeland.

\section{Lyrics of Stari Aga}

Stari Aga, klonuo od bola gleda kule lijepog Istanbula suza pece, staroga junaka pozeleo rodjenog Sandzaka

Eh kad bih ti moj Sandzaku ja mogao doci

Sjenickim poljima, kao nekad proci ne bih vise pozelio anadolskog blaga dosao bih svom Sandzaku Zvizdic Hasanaga

ostao bih u Sandzaku, Aga Hasanaga

Nije Aga izgubio nadu

da se otme anadolskom blagu

on ce doci voljenom Pazaru

makar odmah leg'o u mezaru.

Nije Aga Bosnu zaboravio

ni planine bosanskog bilajeta gdje je nekad mladost ostavljao ocevog i majcinog amaneta
Elderly kneeling in pain with grief Looking at the towers of beautiful Istanbul Old hero burns tears in his eyes

He missed his birthplace Sancak

Well if I could come to you my Sancak If I could pass through the plains of Sjenica, as it once was.

I wouldn't miss the beauties of Anatolia

Zvizdic Hasanaga would come to his own Sancjak

Agha Hasanaga would stay in Sanjak

Agha did not lose hope

Abandon the beauties of Anatolia

He will come to his beloved Pazar (Novi

Pazar)

Even if he's going to enter the grave at that moment

Agha did not forget Bosnia

He didn't forget its mountains.

Once spent his youth

His father's and mother's entrust 


\section{Conclusion}

The homeland is not only a place of birth and living, but it is constructed by the imagination, depending on positive and negative emotions based on religion, the lands of a state, the shedding blood for the sake of these lands, symbols, consanguinity, and descendancy, by attributing sacredness. Migrants have mixed and contradictory feelings about the old and new homeland, since they are influenced by the emotions, caused by the similarities and differences within both homelands; therefore, they may feel the belonging to more than one homeland. So, we can call this kind of mobility the 'Interhomeland migration'. The interhomeland migrants construct their identities according to these feelings, produced in the old and new homelands, whether they are tangible or intangible. I hope, this term can be used for other migration events and diaspora studies, such as the migration of the gastarbeiter from Turkey to Germany or the exchange people from Turkey to Greece and from Greece to Turkey in 1923.

\section{REFERENCES}

Baker, Ulus. (2012). Kanaatlerden imajlara: Duygular sosyolojisine doğru. (From convictions to images: Towards the sociology of affect (. Istanbul: Birikim Publications

Bayart, Jean-François. (1999). Kimlik Yanılsaması (Illusion of identity). Istanbul: Metis Publications.

Bayram, Sibel. (2011). “Boşnak Şiirinde İstanbul” (Istanbul in Bosnian Poetry). Yeni Türk Edebiyatı Araştırmaları Dergisi. 3(5): 53-68.

Deleuze, Gilles. (2000). Spinoza üzerine on bir ders. (Eleven lectures on Spinoza). Ankara: Öteki Publications.

Han, Byung-Chul. (2019). Psikopolitika: Neoliberalizm ve Yeni Íktidar Teknikleri (Psychopolitics: Neoliberalism and New Technologies of Power). Metis Publications.

Jezernik, Bozidar (ed). (2012). Hayallerdeki "Türk" (Imagining the "Turc"). İstanbul: Kitap Publications 
Kaiser, Robert G. (1994). The Geography of Nationalism in Russia and the USSR. Princeton (N.J.): Princeton University Press.

Lawler, Edward J. (2001). "An Affect Theory of Social Exchange." American Journal of Sociology, University of Chicago Press. 107(2): 321-352.

Lomax. Alan. (1956). "Folk Song Style: Notes on a Systematic Approach to the Study of Folk Song”. Journal of the International Folk Music Council, (8):48-50.

Marshall, Gordon. (1999). Sosyoloji Sözlüğü (Dictionary of Sociology). Ankara: Bilim ve Sanat Publications.

Spinoza, (2011). Etika. (Ülken, Hilmi Ziya, Trans.). Ankara: Dost Kitabevi Publications. [Original work published 1678]

Talam, Jasmina. (2013). Folk Musical Instruments in Bosnia and Herzegovina. New Castle upon Tyne: Cambridge Scholars Publishing.

Thrift, Nigel. (2004). "Intensities of feeling: Towards a spatial politics of affect." Geografiska Annaler, 86B(1): 57-78.

Various Artists. (2007). Sevdalinka - Sarajevo Love Songs. (CD) Almanya: Piranha. 